\section{REFERENCES}

1. Serov VN, Sukhikh GT. Akusherstvo i ginekologiya; Klinicheskie recomendacii [Obstetrics and gynecology; Clinical guidelines]. Moskva [Moscow]: GEOTAR-Media. 2014; 4: $1011 \mathrm{p}$.

2. Serov VN, Dubnitskaya LV, Tyutyunnik VL. Vospalitelnye zabolevaniya organov malogo taza: diagnosticheskie kriterii i princhipy lecheniya [Pelvic inflammatory diseases: diagnostic criteria and treatment principles]. Rossiyskiy meditsinskiy zhurnal [Russian medical journal]. 2011; 19: 46-50.

3. Dikke GB. Polimikrobnye associacii v etiologii vospalitelnyh zabolevanii polovyh organov u genshchin [Polymicrobial associations in the etiology of inflammatory diseases of the genital organs in women]. Akusherstvo i ginekologiya [Obstetrics and Gynecology]. 2017; 6: 151-158.

4. Kolesnichenko AA. Vospalitelnye zabolevaniya pridatkov matki: chno novogo? [Inflammatory diseases of the uterine appendages: what's new?]. Molodoy uchenyy [The young scientist]. 2016; 22 (1): 4-17.

5. Murashko AV, Murashko AA. Sovremennye podhody k terapii VZOMT [Modern approaches to the therapy of PID]. Meditsinskiy sovet [Medical advice]. 2014; 9: 103-105.

6. Pitirimova LN, Zagorodneva EA, Gumilevsky BYu. Osobennosti allelnogo polymorfizma genov interleikinov i citokinovyi balans genshchin s nevynashivaniemberemennosti [Features of allelic polymorphism of genes of interleukins and cytokine balance of women with miscarriages]. Akusherstvo i ginekologiya [Obstetrics and gynecology]. 2014; 3: 33-38.

7. Prilepskaya VN, Bebneva TN. Effektivnost immunomodulyatora Galavita v lechenii vospalitelnyh zabolevanii organov malogo taza [The effectiveness of Galovit immunomodulator in the treatment of inflammatory diseases of the pelvic organs]. Rossiyskiy meditsinskiy zhurnal [Russian medical journal]. 2013; 1: 31.

8. Tetelyutina FK, Kopieva OV. Vozmognosti immunnoi korrekcii pri hronicheskih vospalitelnyh zabolevaniyah organov malogo taza [Possibilities of immune correction in chronic inflammatory diseases of pelvic organs]. Sovremennyye problemy nauki i obrazovaniya [Modern problems of science and education]. 2015; 1 (1): 1370-1371.
9. Ali AS, Townes CL, Hall J, Pickard RS. Maintaining a sterile urinary tract: the role of antimicrobial peptides. $J$ Urol. 2009; 182: 21-28.

10. Zasloff M. Antimicrobial peptides, innate immunity, and the normally sterile urinary tract. J Am Soc Nephrol. 2007; 18: 2810-2816.

11. Agier J, Brzezinska-Blaszczyk E. Cathelicidins and defensins regulate mast cell antimicrobial activity. Postepy Hig Med Dosw (Online). 2016; 70: 618-636.

12. Witkowska D, Bartys A, Gamian A. Defensins and cathelicidins as natural peptide antibiotics. Postepy Hig Med Dosw (Online). 2008; 22: 694-707.

13. Aleshina GM, Kokryakov VN, Shamova OV, Orlov DS, Andreeva YuV. Sovremennaya koncepciya ob antimikrobnyh peptidah kak molekulyarnyh faktorah immuniteta [The modern concept of antimicrobial peptides as molecular factors of immunity]. Meditsinskiy akademicheskiy zhurnal [Medical Academic Journal]. 2010; 4: 149-160.

14. Budikhina AS, Pinegin BV. A-defenziny - antimikrobnye peptidy neytrofilov: svoystva i funkcii [A-defensins - antimicrobial peptides of neutrophils: properties and functions]. Immunologiya [Immunology]. 2008; 5: 317-320.

15. Rathinakumar R, Walkenhorst WF, Wimley WC. Broadspectrum antimicrobial peptides by rational combinatorial design and high-throughput screening: the importance of interfacial activity. J Am Chem Soc. 2009; 131: 7609-7617.

16. Zharkova MS, Orlov DS, Kokryakov VN, Shamova OV. Antimikrobnye peptidy mlekopitayushchih: klassifikaciya, biologicheskaya rol, perspektivy prakticheskogo primeneniya [Mammalian antimicrobial peptides: classification, biological role, practical application prospects]. Vestnik Sankt-Peterburgskogo universiteta, Seriya 3 - Biologiya [Bulletin of St Petersburg University, series 3 - Biology]. 2014; 1: 98-114.

17. Schindlbeck C, Schindlbeck D, Dziura D, Mylonas I. Diagnosis of pelvic inflammatory disease (PID): intraoperative findings and comparison of vaginal and intra-abdominal cultures. Arch Gynecol Obstet. 2014; 289 (6): 1263-1269.

18. 2018 European (IUSTI/WHO) Guideline on the Management of Vaginal Discharge. 2018; https://www.iusti.org/ regions/Europe/pdf/2019/Vagdx2018.pdf

\title{
CLINICAL FEATURES OF PULMONARY ARTERIAL HYPERTENSION IN PATIENTS WITH CHRONIC DESTRUCTIVE LUNG TUBERCULOSIS COMBINED WITH CHRONIC OBSTRUCTIVE PULMONARY DISEASE
}

ISMAILZADE JEYKHUN M., PhD, associate professor, deputy Head of the Department of lung diseases of Azerbaijan Medical University, Azerbaijan, AZ1118, Baku, E. Suleymanov str., 2514th quarter, tel. +9(945)039-975-76, e-mail: ism.ceyhun@gmail.com

BAYRAMOV RAFIK I., PhD, associate professor, Head of the Department of lung diseases of Azerbaijan Medical University, Azerbaijan, AZ1118, Baku, E. Suleymanov str., 2514th quarter, tel. +9(945)036-203-62, e-mail: rafiq-bayramov@mail.ru

GURBANOVA ZEYNAB T., assistant of professor of the Department of lung diseases of Azerbaijan Medical University, Azerbaijan, AZ1118, Baku, E. Suleymanov str., 2514th quarte, e-mail: zeynabqurbanova72@gmail.com KADIMOVA ZULFU SH., assistant of professor of the Department of lung diseases of Azerbaijan Medical University, Azerbaijan, AZ1118, Baku, E. Suleymanov str., 2514th quarter, e-mail: z.kadimova12@gmail.com NAGIEVA URFANA B., assistant of professor of the Department of lung diseases of Azerbaijan Medical University, Azerbaijan, AZ1118, Baku, E. Suleymanov str., 2514th quarter, e-mail: nagiyeva.urfana@mail.ru IBRAGIMOV TABIB G., PhD, physician of TB Hospital № 4, Azerbaijan, Baku, M. Sharifli str., tel. +99(450)351-26-96, e-mail: tebib1112@gmail.com

Abstract. Aim. To examine the role of NT-pro brain natriuretic peptide (NT-proBNP) interleykin 6 (IL-6), tumor necrosis factor- $\alpha(T N F-\alpha)$, and C-reactive protein (CRP) as predictors for identification and severity of PAH in patients with CDLT+COPD. Material and methods. Using diagnostic-based approaches included immunochemistry, high-resolution 
computed tomography (HR-CT) Doppler echocardiography (Doppler-Eco) we characterized the biomarkers directly identifying the risk for development of $\mathrm{PAH}$ in patients with chronic lung tuberculosis, detection of cellular immune response. The risk for development of PAH in patients was learned by assessing of proinflammatory cytokines (IL-6, TNF- $\alpha$ ) and proinflammatory peptides (CRP, NT-pro BNP). Depends on volume of irreversible morphological changes related lung tuberculosis all patients were divided in two groups: 1) 26 patients with CDLT+COPD and with PAH, 2) 25 patients with CDLT+COPD without PAH, 12 practically healthy individuals served as controls. All patients have been admitted to the Departments of Medical University. Results and discussion. Our data reveal that proinflammatory cytokines (IL-6, TNF- $\alpha$ ) and proinflammatory peptides (CRP, NT-pro BNP) may play role as predictors for assessment of development severity of PAH in patients with CDTL and COPD. Our study also shown that the high level of proinflammatory cytokines and peptides were associated with more severe PAH in patients. In CDLT+COPD, lung parenchyma, bronchi vessels is involved in complex processes coupling the bronchopulmonary and cardiovascular systems. Conclusions. Chronic lung inflammation with elevation of the level proinflammatory cytokines and peptides have critical contribution of lung parenchyma, bronchi and vessels remodeling and the fringe of nonreversible morphological changes in the lung at PAH in CDLT+COPD.

Key words: chronic obstructive pulmonary disease, chronic destructive lung tuberculosis, pulmonary arterial hypertension, cellular immune response, diaskintest, proinflammatory cytokines and peptides.

For reference: Ismailzade JM, Bayramov RI, Gurbanova ZT, Kadimova ZSh, Nagiyeva UB, Ibragimov TG. Clinical features of pulmonary arterial hypertension in patients with chronic destructive lung tuberculosis combined with chronic obstructive pulmonary disease. The Bulletin of Contemporary Clinical Medicine. 2019; 12 (6): 22-28. DOI: 10.20969/ VSKM.2019.12(6).22-28.

\section{КЛИНИЧЕСКИЕ ОСОБЕННОСТИ ЛЕГОЧНОЙ АРТЕРИАЛЬНОЙ ГИПЕРТЕНЗИИ У БОЛЬНЫХ С ХРОНИЧЕСКИМ ДЕСТРУКТИВНЫМ ТУБЕРКУЛЕЗОМ ЛЕГКИХ В СОЧЕТАНИИ С ХРОНИЧЕСКОЙ ОБСТРУКТИВНОЙ БОЛЕЗНЬЮ ЛЕГКИХ}

\section{ИСМАИЛЗАДЕ ДЖЕЙХУН МОХУББАТ огЛЫ, ДОКТ. фИЛОсофиИ По медицине, доцент, заместитель} зав. кафедрой легочных заболеваний Азербайджанского медицинского университета, Азербайджан, AZ1118, Баку, ул. Э. Сулейманова, 2514-й квартал, тел. +9(945)039-975-76, e-mail: ism.ceyhun@gmail.com БАЙРАМОВ РАФИК ИДРИС оглы, докт. философии по медицине, доцент, зав. кафедрой легочных заболеваний Азербайджанского медицинского университета, Азербайджан, AZ1118, Баку, ул. Э. Сулейманова, 2514-й квартал, тел. +9(945)036-203-62, e-mail: rafiq-bayramov@mail.ru ГУРБАНОВА ЗЕЙНАБ ТАМРЕЛХА гызы, ассистент кафедры легочных заболеваний Азербайджанского медицинского университета, Азербайджан, AZ1118, Баку, ул. Э. Сулейманова, 2514-й квартал, e-mail: zeynabqurbanova72@gmail.com

кАДИМОВА ЗульФу ШАИГ гызы, ассистент кафедры легочных заболеваний Азербайджанского медицинского университета, Азербайджан, AZ1118, Баку, ул. Э. Сулейманова, 2514-й квартал, e-mail: z.kadimova12@gmail.com

НАГИЕВА УРФАНА БАХРАМ гызы, ассистент кафедры легочных заболеваний Азербайджанского медицинского университета, Азербайджан, AZ1118, Баку, ул. Э. Сулейманова, 2514-й квартал, e-mail: nagiyeva.urfana@mail.ru ИБРАГИМОВ ТАБИБ ГАРАШ оглы, докт. философии по медицине, врач Противотуберкулезного диспансера № 4 Минздрава Азербайджана, Азербайджан, Баку, ул. М. Шарифли 163, тел. +99(450)351-26-96, e-mail: tebib1112@gmail.com

Реферат. Цель - изучить роль N-терминального участка мозгового натрийуретического пептида (NT-proBNP), интерлейкина 6 (IL-6), фрактора некроза опухоли- $\alpha$ (TNF- $\alpha$ ) и C-реактивного белка (CRP) в качестве предикторов тяжести легочной артериальной гипертензии у пациентов с хроническим деструктивным туберкулезом легких и хронической обструктивной болезнью легких. Материал и методы. Были обследованы пациенты с хроническим деструктивным туберкулезом легких и хронической обструктивной болезнью легких $(n=51)$. В зависимости от морфологических изменений все пациенты были разделены на две группы: 1-я группа 26 пациентов с хроническим деструктивным туберкулезом легких и хронической обструктивной болезнью легких и легочной артериальной гипертензией, 2-я группа - 25 пациентов с хроническим деструктивным туберкулезом легких и хронической обструктивной болезнью легких без легочной артериальной гипертензии. 12 практически здоровых людей составили группу контроля. С помощью иммунохимических методов были определены уровни провоспалительных цитокинов (IL-6, TNF- $\alpha$ ) и провоспалительных пептидов (CRP, NT-pro BNP). Обследованным проводилась компьютерная томография высокого разрешения (HR-CT) и допплерэхокардиография (Doppler-Echo) для оценки состояния паренхимы легких и степени легочной артериальной гипертензии. Для сравнения и определения значимости количественных различий в парных группах использовался непараметрический критерий Уилкоксона (Манна - Уитни), а между несколькими группами - критерий Крускала - Уоллиса. Корреляции между исследуемыми параметрами определены по критерию Спирмена. Расчеты были выполнены с использованием программного пакета SPSS 20. Результаты и их обсуждение. Наши данные показывают, что провоспалительные цитокины (IL-6, TNF-a) и провоспалительные пептиды (CRP, NT-pro BNP) могут играть роль предикторов оценки тяжести легочной артериальной гипертензии у пациентов с хроническим деструктивным туберкулезом легких и хронической обструктивной болезнью легких, так как коррелируют с более тяжелой легочной артериальной гипертензией. При хроническом деструктивном туберкулезе легких и хронической обструктивной болезни легких паренхима легкого, сосуды бронхов участвуют в сложных процессах взаимодействия бронхолегочной и сердечно-сосудистой систем. Выводы. Хроническое 
воспаление легких с повышенными уровнями провоспалительных цитокинов и пептидов играет решающую роль в ремоделировании бронхов и сосудов, а также необратимых морфологических изменениях в легких при легочной артериальной гипертензии на фоне хронического деструктивного туберкулеза легких и хронической обструктивной болезни легких.

Ключевые слова: хроническая обструктивная болезнь легких, хронический деструктивный туберкулез легких, легочная артериальная гипертензия, клеточный иммунный ответ, Диаскинтест, провоспалительные цитокины и пептиды.

Для ссылки: Клинические особенности легочной артериальной гипертензии у больных с хроническим деструктивным туберкулезом легких в сочетании с хронической обструктивной болезнью легких / Д.М. Исмаилзаде, Р.И. Байрамов, 3.Т. Гурбанова [и др.] // Вестник современной клинической медицины. - 2019. - Т. 12, вып. 6. C.22-28. DOI: 10.20969/VSKM.2019.12(6).22-28.

C hronic destructive lung tuberculosis (CDLT) is one of the forms of pulmonary tuberculosis in clinical forms, is characterized by progressive course. Chronic obstructive pulmonary disease (COPD), regardless of the degree of severity, is manifested by a chronic inflammatory process with a predominant lesion of the distal respiratory tract and pulmonary parenchyma. For patients with COPD, a decrease in the maximum expiratory flow rate and a slow deterioration in the gas exchange function of the lungs are characteristic, which reflects the irreversible nature of airway obstruction. The etiology of COPD is directly related to the risk factors that cause the disease. COPD is a clinical example of a polygenic disease in which the effect of external risk factors is realized when there is a certain genetic predisposition. Certain diagnostic difficulties arise when a combination of pulmonary tuberculosis especially its chronic destructive forms, and COPD because of similar clinical manifestations of both diseases. In the presence of such a combination on the 1st place always exposed tuberculosis and assigns the appropriate chemotherapy for TB doctors (phthisiatricians) often forget this is no less urgent than pulmonary tuberculosis, another important disease - chronic obstructive pulmonary disease. As a result of inadequate treatment of COPD, frequent exacerbations of the disease occur, which are often perceived as exacerbations of a specific process and, correspondingly, accompanied by an intensification of the chemotherapy regimen. As a result of frequent exacerbation and constant progression of COPD, this category of patients often has complications of a combined pathology, one of which is pulmonary hypertension, often leading to the death of patients.

Annually 8,6 million new cases and 1,3 million deaths are attributed to tuberculosis [1]. The traditionally recognized clinical presentation of chronic lung tuberculosis is fibrocavitary disease [2]. During pulmonary tuberculosis (TB), proinflammatory cytokines (IL-6, TNF- $\alpha$ ) rich to the inflamed lung [3]. T-cells regulation of immune response in lung tuberculosis is associated with accumulation of cytokines included IL-1, IL-6, IL-8, GC-SF, and monocyte chemoattractant factor (MCF-1), whereas production of granulocyte macrophage colony-stimulating factor and macrophage inflammatory protein-1 was reduced [4]. The implications of this are that local immune dysregulation can be responsible for disease manifestations.

One of most common symptoms of chronic and persistent lung tuberculosis is dyspnea [5]. In such patients, together with irreversible morphological changes in lung tissue (parenchyma) these changes may affect also lung vascularity and may developed vascular remodeling in pulmonary arteries [6]. This mechanism together with hypoxic vasoconstriction may play important role for development in of $\mathrm{PAH}$ in such patients [7, 8]. PAH is an established complication of CDLT and COPD [9, 10] and they have been demonstrated to be an independent risk factors for death [11]. Its prevalence depends on severity of irreversible morphological changes in lung parenchyma, and PAH typically occurs in a subpopulation of patients with CDLT and COPD with significantly morphological changes, when ventilation perfusion mismatching is severe and associated with hypoxia [12, 13]. During reference analysis we identified limited data related with some biomarkers which may play role as predictor for development and severity of $\mathrm{PAH}$ in patients with CDLT+COPD.

The aim of the present study was to describe the clinical, biomarkers and computed tomography (CT) characteristics of patients with CDLT+COPD with or without PAH.

Material and methods. Data were retrieved from all consecutive patients with CDLT+COPD older than 40 years of age who were referred to the tertiary unit of our university between January 2012 and May 2017 for complete examination of chronic respiratory failure and treatment. The study was performed in accordance with the ethical standards of the bioethical committee, developed in accordance with the Helsinki Declaration of the World Medical Association «Ethical Principles of Medical Research Involving Human Subjects» with the amendments of 2013 and the «Rules of Ethical Conduct of Medical Workers» approved by the Order (№ 137) of the Ministry of Health of the Republic of Azerbaijan dated 29.12.2011. The patients and persons of control group had to undergo a standardized panel of investigations, including carefully assembled histories, physical examinations, X-ray examination, explored the peripheral blood (complete blood count) and sputum examination on the presence of AFB. Detection of cellular immune response carried out using Diaskintest based on an evaluation of delayed-type hypersensitivity. We used the interdermal injection of Diaskintest at a dose of $2 \mathrm{mkg}$ in $0,1 \mathrm{ml}$, containing ESAT6-CFP10 (Leceo, Russia) present in virulent strains of MBT. The reactions were evaluated visually after $72 \mathrm{~h}$ and measured the size of induration in millimeters. The result were considered negative in the absence of infiltration, doubtful if hyperemia without infiltration, positive if there is infiltration (papules) of any size, hyperegic when the diameter of infiltration $15 \mathrm{~mm}$ and more, formation vesicle and necrosis and (or) the presence of lymphangitis, lymphadenitis. pulmonary 
function test a (PFTs), arterial blood gas analysis, 6-minute walk test, blood tests (IL-6, TNF- $\alpha$, CRP, NTpro-BNP), transthoracic Doppler echocardiography, computed tomography, and right heart catheterization (RHC) for the purpose of our study, the inclusion criterion was a diagnosis of chronic lung tuberculosis based on characteristic symptoms (e.g. sputum smear and culture for mycobacterium tuberculosis, dyspnea, cough) associated with nonreversible morphological changes in lung tissue on HR-CT PFTs were assessed by using bodyplethysmography (Body Box, Hyp Air Compact). PH was defined as PAPm $\geq 25$ $\mathrm{mmHg}$ assessed by RHC. The diagnosis of COPD was established according to the recommendations of GOLD (2016) on diagnosis, treatment, the presence of risk factors for COPD and post bronchodilator FEV1 to FVC ratio of $<70 \%$. Spirometry with bronchodilator test (inhalation sympathomimetic with short-acting $\beta 2$ agonist Ventolin «Glaxo Smith Kline») (gsk) - 2 doses = $20 \mu \mathrm{g}$ ) was used with measurement of bronchodilation response after 15 minutes. The spirometry study was performed using the Bodytest device (Erich Jaeger, Germany) and SPM - 300 (Bionet, South Korea) in accordance with the criteria proposed by the joint group of experts of the American Thoracic and European Respiratory Society (ATS/ERS). The actual values of the spirographic indexes, the registration of the P-FEV curve were compared with the predicted values developed by the experts of the European Community of Coal and Steel (1983) and evaluated the changes in indicators according to the GOLD recommendations. Proinflammatory cytokines (IL-6, TNF- $\alpha$ ) and proinflammatory peptides (CRP, NT-pro $\mathrm{BNP}$ ), high resolution computed tomography (HR-CT), Doppler echocardiography (Doppler Echo) and right heart catheterization ( $\mathrm{RHC}$ ), examination methods have been used in an effort to fulfill the assigned tasks.

Echocardiography $(\mathrm{ECHO})$ examination was carried out with Aloka-1700 scanner (using 3mhz ultrasound transducer).

The concentration of IL- 6 and TNF- $\alpha$ in blood serums is determined using a standard reagent kit produced by Human (Germany), by means of an immunoassay method, the principle of which is described above. The measurements have been carried out using an immunoassay analysis apparatus, STAT Fax 303 Plus, US.

The principle behind the method for determining the amount of CRP in a blood serum is based on the creation of an immune complex against it using the antibodies in a specific serum (latex reagent). This is accompanied by a visible agglutination of a latex reagent (Human, Germany).

The NUP concentration was determined with the help of a standard reagent kit produced by Human (Germany). This was carried out by using two-site, noncompetitive immunoassays method (also known as «sandwich» type immunoassay) (N-terminal pro-B-type natriuretic peptide, NT Pro-BNP).

The principle of the method is based on the interaction, in a patient's blood serum, between monoclonal mouse antibodies that cover the walls of the test tube of free NT pro-BNP and biotinized polyclonal rabbit antibodies prepared against the human NUP and the combination of alkaline phosphatase and conjugated streptavidin.

The results were evaluated by measuring the intensity of the color produced by conjugation with a specific chromogen (chromogenic substrate).

To compare and determine the significance of differences of quantitative values in paired groups, nonparametric Wilcoxon test was used (Mann-Whitney), and between multiple groups, Kruskal-Wallis test. The correlations between the studied parameters were defined using Spearman criterion. The calculations were performed using SPSS-20 software package.

Results and discussion. A total of 51 patients with CDLT met the inclusion and exclusion criteria. Demographic, respiratory function, biologic and hemodynamic data of the study population are presented in table 1.

There was no difference between CDLT+COPD patients with $(n=26)$ and those without $\mathrm{PAH}(n=25)$ regarding age and sex ratio. In the comparison groups

Table 1

Patient characteristics

\begin{tabular}{|c|c|c|c|c|}
\hline Characters & $\begin{array}{l}\text { CDLT with COPD, without PAH } \\
\qquad(n=25)\end{array}$ & $\begin{array}{l}\text { CDLT+COPD with PAH } \\
\qquad(n=26)\end{array}$ & $\begin{array}{l}\text { Control } \\
(n=12)\end{array}$ & $p$ value \\
\hline Sex, $m / f$ & $20 / 5$ & $18 / 8$ & $9 / 3$ & 0,677 \\
\hline Age, year & $\begin{array}{c}45,2 \pm 2,5 \\
(29-69) \\
\end{array}$ & $\begin{array}{c}44,7 \pm 2,2 \\
(29-69) \\
\end{array}$ & $\begin{array}{c}43,2 \pm 3,2 \\
(25-59) \\
\end{array}$ & 0,905 \\
\hline Diaskintest & Positive & Positive & Negative & \\
\hline Dyspnea, mMRCs & $\begin{array}{c}0,92 \pm 0,14 \\
(0-2)\end{array}$ & $\begin{array}{c}3,31 \pm 0,23 \\
(1-5) * * \star \wedge \wedge \wedge\end{array}$ & $\begin{array}{c}0,50 \pm 0,15 \\
(0-1)\end{array}$ & $<0,001$ \\
\hline \multicolumn{5}{|c|}{ Respiratory function } \\
\hline FEV1,\% & $\begin{array}{c}69,7 \pm 1,3 \\
(58,1-78,4)^{* * *}\end{array}$ & $\begin{array}{c}68,4 \pm 1,1 \\
(56,6-77,9)^{* * * \wedge \wedge \wedge}\end{array}$ & $\begin{array}{c}93,3 \pm 1,0 \\
(89-99)\end{array}$ & $<0,001$ \\
\hline FVC, $\%$ & $\begin{array}{c}59,4 \pm 1,5 \\
(45-67)^{\star * *}\end{array}$ & $\begin{array}{c}47,3 \pm 1,4 \\
(36-59)^{\star \star * \wedge \wedge \wedge}\end{array}$ & $\begin{array}{l}99,2 \pm 1,6 \\
(90-106)\end{array}$ & $<0,001$ \\
\hline FEV1/FVC & $\begin{array}{c}98,1 \pm 2,2 \\
(79,3-123,9)\end{array}$ & $\begin{array}{c}65,8 \pm 1,1 \\
(55-74,7) \\
\end{array}$ & $\begin{array}{c}94,3 \pm 1,6 \\
(84,8-100,0)\end{array}$ & 0,430 \\
\hline RV1,\% & $\begin{array}{l}68,46 \pm 2,67 \\
(58-79)^{\star *}\end{array}$ & $\begin{array}{c}82,9 \pm 1,0 \\
(72-90) * * * \wedge \wedge\end{array}$ & $\begin{array}{c}94,9 \pm 0,8 \\
(90-99)\end{array}$ & $<0,001$ \\
\hline
\end{tabular}




\begin{tabular}{|c|c|c|c|c|}
\hline Characters & $\begin{array}{l}\text { CDLT with COPD, without PAH } \\
\qquad(n=25)\end{array}$ & $\begin{array}{c}\text { CDLT+COPD with PAH } \\
(n=26)\end{array}$ & $\begin{array}{l}\text { Control } \\
(n=12)\end{array}$ & $p$ value \\
\hline TLC,\% & $\begin{array}{c}80,6 \pm 1,3 \\
(68-93)^{* * *}\end{array}$ & $\begin{array}{c}70,7 \pm 1,6 \\
(60-86)^{* * \star \wedge \wedge \wedge}\end{array}$ & $\begin{array}{c}89,3 \pm 1,3 \\
(84-96)\end{array}$ & $<0,001$ \\
\hline DLco, $\%$ & $\begin{array}{l}65,4 \pm 1,4 \\
(54-76)^{* * *} \\
\end{array}$ & $\begin{array}{c}48,8 \pm 1,6 \\
(33-61)^{* \star \star \wedge \wedge \wedge} \\
\end{array}$ & $\begin{array}{c}88,8 \pm 1,3 \\
(82-96)\end{array}$ & $<0,001$ \\
\hline \multicolumn{5}{|c|}{ Arterial blood gases (room air) } \\
\hline $\mathrm{PaO}_{2}, m m \mathrm{Hg}$ & $\begin{array}{r}76,3 \pm 1,5 \\
(65-92)^{* * *} \\
\end{array}$ & $\begin{array}{c}56,2 \pm 2,2 \\
(36-75)^{* * * \wedge \wedge \wedge} \\
\end{array}$ & $\begin{array}{c}94,3 \pm 1,0 \\
(86-98) \\
\end{array}$ & $<0,001$ \\
\hline $\mathrm{PaCO}_{2}, \mathrm{~mm} \mathrm{Hg}$ & $\begin{array}{l}42,6 \pm 0,6 \\
(37-46) * *\end{array}$ & $\begin{array}{c}43,0 \pm 1,3 \\
(32-55)\end{array}$ & $\begin{array}{c}39,6 \pm 0,8 \\
(36-45)\end{array}$ & 0,071 \\
\hline \multicolumn{5}{|c|}{ Biological tests } \\
\hline CRP, $m g / m l$ & $\begin{array}{l}13,2 \pm 0,6 \\
(6-19) * * *\end{array}$ & $\begin{array}{c}19,5 \pm 1,4 \\
(8-32)^{* \star \star \wedge \wedge \wedge}\end{array}$ & $\begin{array}{l}2,9 \pm 0,3 \\
(1,2-4,2)\end{array}$ & $<0,001$ \\
\hline II-6, pg/ml & $\begin{array}{c}27,3 \pm 1,9 \\
(15,6-45,6)^{* * *}\end{array}$ & $\begin{array}{c}38,2 \pm 1,9 \\
(20,1-59,2)^{* * \star \wedge \wedge \wedge} \\
\end{array}$ & $\begin{array}{c}14,2 \pm 2,8 \\
(2,9-30,6) \\
\end{array}$ & $<0,001$ \\
\hline TNFa, $p g / m l$ & $\begin{array}{l}69,3 \pm 1,7 \\
(59-85)^{* * *}\end{array}$ & $\begin{array}{c}86,1 \pm 3,4 \\
(60-137)^{* \star \star \wedge \wedge \wedge}\end{array}$ & $\begin{array}{c}35,3 \pm 5,4 \\
(11-67)\end{array}$ & $<0,001$ \\
\hline NTproBNP, ng/ml & $\begin{array}{l}652,8 \pm 44,2 \\
(390-1000)^{*}\end{array}$ & $\begin{array}{c}874,8 \pm 77,2 \\
(380-1800)^{* \star \wedge}\end{array}$ & $\begin{array}{c}490,3 \pm 48,0 \\
(340-785) \\
\end{array}$ & 0,001 \\
\hline LVEF (echo), \% & $\begin{array}{c}54,3 \pm 0,7 \\
(49-62) \\
\end{array}$ & $\begin{array}{c}63,8 \pm 1,6 \\
(49-77)^{* * * \wedge \wedge \wedge} \\
\end{array}$ & $\begin{array}{c}52,9 \pm 0,8 \\
(49-58)\end{array}$ & $<0,001$ \\
\hline \multicolumn{5}{|c|}{$R H C$} \\
\hline PAPs, $m m / H g$ & $\begin{array}{l}36,2 \pm 2,2 \\
(25-48)^{* *}\end{array}$ & $\begin{array}{c}45,6 \pm 1,0 \\
(39-50))^{* * \star \wedge \wedge} \\
\end{array}$ & $\begin{array}{c}25,0 \pm 0,9 \\
(23-29) \\
\end{array}$ & $<0,001$ \\
\hline $\mathrm{PAPm}, \mathrm{mm} / \mathrm{Hg}$ & $\begin{array}{c}27,4 \pm 1,3 \\
(21-34)^{* \star *} \\
\end{array}$ & $\begin{array}{c}32,0 \pm 1,4 \\
(24-38) * * \star \wedge\end{array}$ & $\begin{array}{c}13,7 \pm 0,7 \\
(12-16)\end{array}$ & $<0,001$ \\
\hline $\mathrm{PAPd}, \mathrm{mm} / \mathrm{Hg}$ & $\begin{array}{l}15,7 \pm 1,4 \\
(9-23)^{* *} \\
\end{array}$ & $\begin{array}{c}20,3 \pm 1,7 \\
(12-28)^{* * *}\end{array}$ & $\begin{array}{l}9,8 \pm 0,7 \\
(7-12)\end{array}$ & 0,001 \\
\hline PVR, w.u. & $\begin{array}{l}3,11 \pm 0,16 \\
(2,3-3,7)^{* *}\end{array}$ & $\begin{array}{c}4,24 \pm 0,28 \\
(2,9-5,2)^{* * * \wedge \wedge} \\
\end{array}$ & $\begin{array}{c}2,35 \pm 0,14 \\
(2-2,9)\end{array}$ & 0,001 \\
\hline PCWP, $m m / H g$ & $\begin{array}{l}6,03 \pm 0,22 \\
(4,8-7,2)^{* *}\end{array}$ & $\begin{array}{l}6,65 \pm 0,21 \\
(5,8-7,6)^{* * *}\end{array}$ & $\begin{array}{c}4,70 \pm 0,18 \\
(4-5,2)\end{array}$ & 0,001 \\
\hline $\mathrm{Cl}, \mathrm{L} / \mathrm{min} / \mathrm{m}^{2}$ & $\begin{array}{l}2,89 \pm 0,06 \\
(2,6-3,2) \text { * }\end{array}$ & $\begin{array}{l}2,92 \pm 0,07 \\
(2,6-3,3) \text { * }\end{array}$ & $\begin{array}{c}3,13 \pm 0,09 \\
(2,8-3,4)\end{array}$ & 0,085 \\
\hline AP/AO & $\begin{array}{l}0,842 \pm 0,021 \\
(0,75-0,96) *\end{array}$ & $\begin{array}{c}0,986 \pm 0,021 \\
(0,86-1,06)^{* * * \wedge \wedge \wedge}\end{array}$ & $\begin{array}{c}0,757 \pm 0,017 \\
(0,7-0,8)\end{array}$ & $<0,001$ \\
\hline
\end{tabular}

Note: 1 ) a statistically significant difference (U-Wilkoxon (Mann - Whitney):

- with the control group: ${ }^{*} p<0,05 ;{ }^{* *} p<0,01 ;{ }^{* * *} p<0,001$;

- with indicators of Group without PAH: ${ }^{\wedge} p_{1}<0,05 ;{ }^{\wedge} p_{1}<0,01 ;{ }^{\wedge \wedge} p_{1}<0,001$

2) a statistically significant difference between groups (Kruskal - Wallace) - $p$ value.

Definition of abbreviations: CDLT-chronic destructive lung tuberculosis; LVEF-left ventricular ejection fraction; mMRCs - modified Medical Research Council scale; PAPd = diastolic pulmonary arterial pressure; PAPm = mean pulmonary arterial pressure; PAPs = systolic pulmonary arterial pressure; $\mathrm{PCWP}=$ pulmonary capillary wedge pressure; $\mathrm{PAH}=$ pulmonary arterial hypertension; $\mathrm{PVR}=$ pulmonary vascular resistance; $\mathrm{RHC}=$ right heart catheterization; $\mathrm{RV}=$ residual volume; $T L C=$ total lung capacity; $\mathrm{DLco}=$ transfer lung capacity of carbon monoxide. AP/AO = diameter ratio between the pulmonary arterial truncus and the ascending aorta.

(CDLT with COPD without PAH and CDLT+COPD with $\mathrm{PAH}$ ) no one had discovered negative anergy. In both groups of comparison, different intensity, positive reactions to Diaskintest were revealed. Negative Diaskintest was detected in all persons belonging to the control group. The FEV1 was also not significantly different. DLco measurement was significantly less in patients with PAH $(p<0,001)$ which suggested about more markedly affecting area of lung (two and more pulmonary lobes) with nonreversible morphological changes. Hypoxemia was more severe in patients CDLT+COPD with PAH.

At the vascular level, the diameter ratio between the pulmonary arterial truncus and the ascending aorta $(A P / A O)$ was higher in patients with CDLT+COPD with $\mathrm{PAH}(p<0,001)$. The occurrence of bronchiectasis also was higher in patients with CDLT+COPD with $\mathrm{PAH}(p<0,001)$. It suggested that in such patient's chronic destructive lung tuberculosis nonreversible morphological changes are not single mechanism for development of PAH.

When we assessed each CDLT+COPD population with and without PAH separately, as well as the whole study population, we found that positive correlation coefficients between PAPm and the extent of nonreversible morphological changes in the lung parenchyma (table 2).

The analysis of proinflammatory cytokines and peptides shown positive correlation between these and the level of mPAP (Figure). More significantly elevation of mPAP was noted in patients with NT-pro BNP level more than $500 \mathrm{ng} / \mathrm{ml}$. 
Correlation Matrix between PAPm, Respiratory Function, and CT parameters in 51 patients with CDLT+COPD

\begin{tabular}{|c|c|c|c|c|c|c|c|c|}
\hline \multicolumn{2}{|c|}{ Characters } & TLC & $\mathrm{PO}_{2}$ & CRP & II-6 & proBNP & PAPm & AP/AO \\
\hline \multirow[t]{2}{*}{ TLC } & $r$ & & $0,411^{* *}$ & $-0,200$ & $-0,471^{* *}$ & $-0,322^{*}$ & 0,131 & $-0,085$ \\
\hline & $p$ & & 0,003 & 0,160 & 0,000 & 0,021 & 0,582 & 0,722 \\
\hline \multirow[t]{2}{*}{$\mathrm{PaO}_{2}$} & $r$ & & & $-0,225$ & $-0,508^{* *}$ & $-0,203$ & $-0,094$ & $-0,649^{* *}$ \\
\hline & $p$ & & & 0,112 & 0,000 & 0,152 & 0,693 & 0,002 \\
\hline \multirow[t]{2}{*}{ CRP } & $r$ & & & & $0,363^{* *}$ & 0,114 & 0,282 & $0,597^{* *}$ \\
\hline & $p$ & & & & 0,009 & 0,424 & 0,229 & 0,005 \\
\hline \multirow[t]{2}{*}{ II-6 } & $r$ & & & & & 0,159 & 0,137 & 0,364 \\
\hline & $p$ & & & & & 0,265 & 0,565 & 0,115 \\
\hline \multirow[t]{2}{*}{ NTproBNP } & $r$ & & & & & & $-0,059$ & $-0,088$ \\
\hline & $p$ & & & & & & 0,803 & 0,712 \\
\hline \multirow[t]{2}{*}{ PAPm } & $r$ & & & & & & & 0,331 \\
\hline & $p$ & & & & & & & 0,154 \\
\hline
\end{tabular}

Note: Correlation is significant (2-sided) at the level: ${ }^{*} p<0,05 ;{ }^{*} p<0,01$.

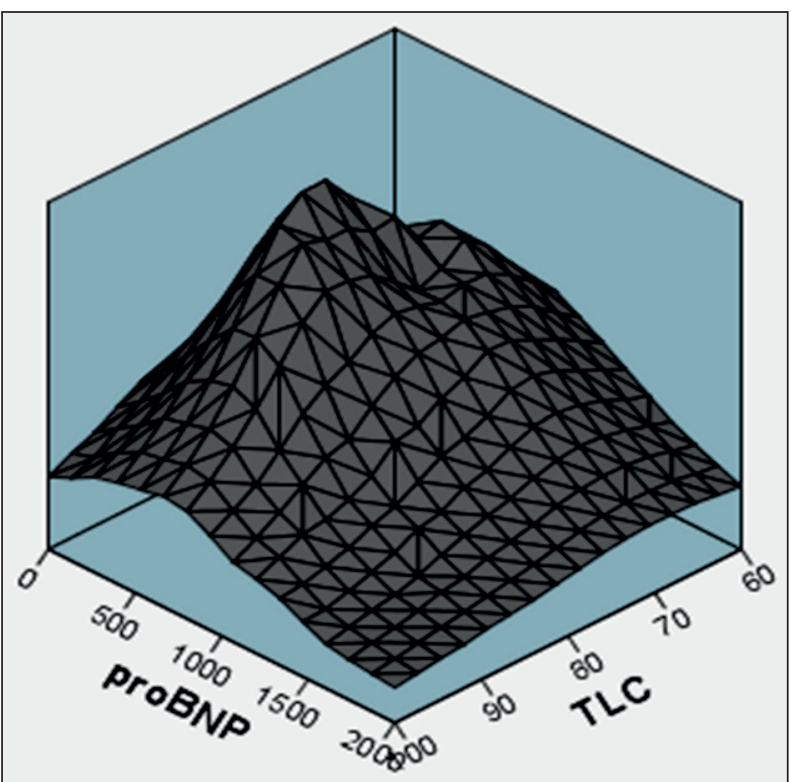

Correlations between mean pulmonary arterial pressure (PAPm) and NTproBNP in patients with CDLT+COPD with and without $\mathrm{PAH}$

Our results may indicate that, using relevant information related to vessels (AP/AO), extent of nonreversible morphological changes in lung, hypoxia $\left(\mathrm{PaO}_{2}\right)$, and more important to NTpro-BNP level, a multivariate model can improve this alternative strategy to estimate PAPm noninvasively.

Finally, our results give evidence that in CDLT+COPD, lung parenchyma, bronchi vessels is involved in complex processes coupling the bronchopulmonary and cardiovascular systems. This may provide further understanding of the burden of lung parenchyma and airway remodeling to explain CDLT+COPD severity and mortality. Specifically, our study suggests a critical contribution of lung parenchyma, bronchi and vessels remodeling to explain $\mathrm{PAH}$ in CDLT+COPD at the fringe of nonreversible morphological changes in the lung, gas exchange, and chronic lung inflammation with elevation of the level proinflammatory cytokines and peptides.

Transparency of the study. The study did not have sponsorship. The authors are solely responsible for the provision of the final version of the manuscript for publication.

Declaration of financial or other relationships. All authors participated in the conception and design of the study and in the writing of the manuscript. The final version of the manuscript was approved by all the authors. The authors did not receive a fee for the study.

\section{ЛИТЕРАТУРА}

1. Regulatory $\mathrm{T}$ cells attemate mycobacterial stasis in alveolar and blood derived macrophages from patients with tuberculosis / P.L. Semple, A.B. Binder, M. Davids [et al.] // Am. J. Respir. Crit. Care Med. - 2013. - Vol. 187. P.1249-1258.

2. Increased frequency of myeloid derived suppressor cells during active tuberculosis and after recent mycobacterium tuberculosis infection suppresses T-cell function / N. Plessis, L. Locbenberg, M. Kriel [et al.] // Am. J. Respir. Crit. Care Med. - 2013. -Vol. 188. - P.724-732.

3. $\mathrm{S} 100 \mathrm{~A} 8 / \mathrm{A} 9$ proteins mediate neutrophilic inflammation and lung pathology during tuberculosis / R. Gopai, L. Monin, D. Torres [et al.] // Am. J. Respir. Crit. Care Med. - 2013. - Vol. 118. - P.1137-1146.

4. Comstock, G.W. Tuberculosis morbidity in the U.S. Navy: its distribution and decline / G.W. Comstock, L.B. Edwards, V.T. Livesay // Am. Rev. Respir. Dis. - 1974. - Vol. 110. P.572-580.

5. Tuberculosis in the immunocompromised host / M. Sester D. Bumbacea, R. Duarte, C. Lange // Eur. Respir. Monogr. - 2012. - Vol. 58. - P.230-241.

6. Pulmonary hypertension in chronic lung diseases / W. Seeger, Y. Adir, J.A. Barbera [et al] // J. An Coll Cardiol. - 2013. - Vol. 62 (25 suppl). - P.109-116.

7. Wrobel, J.P. Mechanisms of pulmonary hypertension in chronic obstructive pulmonary disease: a pathophysiologic review / J.P. Wrobel, B.R. Tompson, T.J. Williams // J. Heart lung Transplant. - 2012. - Vol. 31. - P.557-564.

8. Role for interleykin-6 in COPD - related pulmonary hypertension / A. Chaovat, L. Savale, C.T. Chovaid [et al.] // Chest. - 2009. - Vol. 136. - P.678-687.

9. The prediction of small airway dimensions using computed tomography / Y. Nakomo, J.C. Wong, P.A. de Jong, L. Buzatu [et al.] // Am. J. Respir. Crit. Care Med. - 2005. Vol. 171. - P.142-146.

10. CT-scan-measured pulmonary artery to aorta ratio and echocardiography for detecting pulmonary hypertension in severe COPD / A.S. Iyer J.M. Wells, S. Vishin [et al.] // Chest. - 2014. - Vol. 145. - P.824-832. 
11. Inflammation in bronchial biopsies of subjects with chronic bronchitis: inverse relationship of CD8+T-lymphocytes with FEV 1 / T.C. O'Shaughnessy, T.W. Ansavi, N.C. Barnes, P.K. Jeffery // Am. J. Respir. Crit. Care Med. - 1997. Vol. 155. - P.852-857.

12. Kamazawa, $A$. Vascular endothelial growth factor as a noninvasive marker of pulmonary vascular remodeling in patients with bronchitis - type of COPD / A. Kamazawa, K. Asai, S. Nonuva // Respir. Res. - 2007. - Vol. 8. - P.22.

13. Rahagi, F.N. Cardiopulmonary coupling in chronic obstructive pulmonary disease: the role of imaging / F.N. Rahagi, E.J. Van Beek, G.R. Washko // J. Thorac. imaging. - 2014. - Vol. 29. -P.80-91.

\section{REFERENCES}

1. Semple PL, Binder AB, Davids M, Mavedza A, Van ZylSmit RN, Dheda K. Regulatory T cells attemate mycobacterial stasis in alveolar and blood derived macrophages from patients with tuberculosis. Am J Respir Crit Care Med. 2013; 187: 1249-1258.

2. Plessis N, Locbenberg L, Kriel M, von Groote-Bidingmaier F, Ribechini E, Loxton AG, Van Helden PD, Lutz MB, Walze G. Increased frequency of myeloid derived suppressor cells during active tuberculosis and after recent mycobacterium tuberculosis infection suppresses T-cell function. Am J Respir Crit Care Med. 2013; 188: 724-732.

3. Gopai R Monin L, Torres D, Slight S, Mehra S, Mc Kenna KC, Fallert Junesko BA, Reinhart TA, Kolls J, BaezSaldana R, et al. S100 A8/A9 proteins mediate neutrophilic inflammation and lung pathology during tuberculosis. Am J Respir Crit Care Med. 2013; 118: 1137-1146.

4. Comstock GW, Edwards LB, Livesay VT. Tuberculosis morbidity in the US Navy: its distribution and decline. Am Rev Respir Dis. 1974; 110: 572-580.
5. Sester M Bumbacea D, Duarte R, Lange C. Tuberculosis in the immunocompromised host. Eur Respir Monogr. 2012; 58: 230-241.

6. Seeger W, Adir Y, Barbera JA, Champion H, Coghlan JG, Cottin V, De Marco T, Galie N, Ghio S, Gibbs S, et al. Pulmonary hypertension in chronic lung diseases. J An Coll Cardiol. 2013; 62 (25 suppl): 109-116.

7. Wrobel JP, Tompson BR, Williams TJ. Mechanisms of pulmonary hypertension in chronic obstructive pulmonary disease: a pathophysiologic review. J Heart lung Transplant. 2012; 31: 557-564.

8. Chaovat A, Savale L, Chovaid C Til, Srtrymf B, Canvet M, Maitre B, Housset B, Brandt L, le Corvoisier $P$, et al. Role for interleukin- 6 in COPD - related pulmonary hypertension. Chest. 2009; 136: 678-687.

9. Nakomo Y, Wong JC de Jong PA, Buzatu L, Nagao T, Coxson HO, Elliott WM, Hogg JS, Pare PD. The prediction of small airway dimensions using computed tomography. Am J Respir Crit Care Med. 2005; 171: 142-146.

10. Iyer AS, Wells JM, Vishin S, Bhatt SP, Wille KM, Drans Field MT. CT-scan-measured pulmonary artery to aorta ratio and echocardiography for detecting pulmonary hypertension in severe COPD. Chest. 2014; 145: 824-832.

11. O'Shaughnessy TC, Ansavi TW, Barnes NC, Jeffery PK. Inflammation in bronchial biopsies of subjects with chronic bronchitis: inverse relationship of CD 8+ T lymphocytes

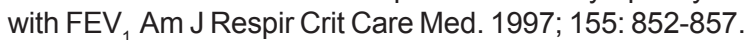

12. Kamazawa A, Asai K, Nonuva S. Vascular endothelial growth factor as a noninvasive marker of pulmonary vascular remodeling in patients with bronchitis - type of COPD. Respir Res. 2007; 8: 22.

13. Rahagi FN, Van Beek EJ, Washko GR. Cardiopulmonary coupling in chronic obstructive pulmonary disease: the role of imaging. J Thorac imaging. 2014; 29: 80-91.

\title{
ДИНАМИКА КОЛИЧЕСТВА И ОБЪЕМА ХИРУРГИЧЕСКИХ ОПЕРАЦИЙ УЗЛОВЫХ ФОРМ ЗОБА В УСЛОВИЯХ ЙОДООБЕСПЕЧЕННОСТИ (1984-1990) И ЙОДОДЕФИЦИТА (1999-2005) В УЗБЕКИСТАНЕ
}

\author{
КАРИМОВА МУКИМА МУХАМАДСАДИКОВНА, ORCID ID: 0000-0001-7528-6400; аспирант-соискатель кафедры \\ эндокринологии с детской эндокринологией Ташкентского педиатрического медицинского института, Узбекистан, \\ 100140, Ташкент, ул. Богишамол, 223; врач-эндокринолог Ферганского областного эндокринологического \\ диспансера Министерства здравоохранения Республики Узбекистан, Узбекистан, Ферганская обл., 151111, \\ Маргилан, ул. Эшангузар, 130A, тел. +99(871)260-31-26, e-mail: mukimaxon@mail.ru \\ ИСМАИЛОВ САИД ИБРАГИМОВИЧ, SCOPUS ID: 57200910444; докт. мед. наук, профессор, зав. кафедрой \\ эндокринологии с детской эндокринологией Ташкентского педиатрического медицинского института, Узбекистан, \\ 100140, Ташкент, ул. Богишамол, 223,тел.+99(871)260-31-26, e-mail: ismailov.said@list.ru
}

Реферат. Цель исследования - изучить динамику количества и объема хирургических операций узловых фрорм зоба в условиях йодообеспеченности (1984-1990) и йододефицита (1999-2005) в Узбекистане по архивным данным отделения эндокринной хирургии Научно-исследовательского института эндокринологии Министерства здравоохранения Республики Узбекистан (НИИ эндокринологии МЗ РУз). Материал и методы. Представлены данные из историй болезни 4256 больных, оперированных по поводу узлового зоба с 1984 по 2005 г. в НИИ эндокринологии МЗ РУз. Количество и характер (объем) хирургического вмешательства при узловом зобе были проанализированы по архивным данным. Результаты и их обсуждение. С 1984 по 2005 г. в НИИ эндокринологии МЗ РУз были прооперированы 4256 больных по поводу узлового зоба. В годы йодообеспеченности (1984-1990) количество таких операций было меньше, а в годы йододефицита (1999-2005) наблюдается их резкое увеличение. Количество более радикальных и агрессивных операций на щитовидной железе при узловом зобе за годы йододефицита резко возросло по сравнению с годами йодообеспеченности: гемитиреоидэктомия от 13 до 163 случаев, тотальная тиреоидэктомия от 7 до 90 случаев. Количество экономных резекций щитовидной железы изменилось сравнительно немного (от 27 до 35 операций) за счет увеличения количества многоузловых зобов, требующих более радикальных операций. В годы йододефицита стали преобладать субтотальные и тотальные тиреоидэктомии, в том числе за счет увеличения числа карцином щитовидной железы: количество папиллярного рака увеличилось с 44 до 135, медуллярного - с 9 до 65, регистрированы случаи анапластического рака от 0 до 39. Выводы. В условиях йододесрицита (1999-2005) возрастает количество узловых и многоузло- 